\title{
High School Completion
}

National Cancer Institute

\section{Source}

National Cancer Institute. High School Completion. NCI Thesaurus. Code C67136.

Indicates that a person has attended high school and has received a high school diploma. 